\title{
Genetic diversity of gabiroba based on random amplified polymorphic DNA markers and morphological characteristics
}

\author{
E.S. de Assis ${ }^{1}$, E.F. dos Reis ${ }^{1}$, J.F.N. Pinto ${ }^{1}$, L.A.S. Contim ${ }^{1}$ and L.A.S. Dias ${ }^{2}$ \\ ${ }^{1}$ Departamento de Biologia, Universidade Federal de Goiás, Jataí, GO, Brasil \\ ${ }^{2}$ Departamento de Fitotecnia, Universidade Federal de Viçosa, Viçosa, MG, Brasil \\ Corresponding author: E.F. dos Reis \\ E-mail: edesio7@brturbo.com.br
}

Genet. Mol. Res. 12 (3): 3500-3509 (2013)

Received July 13, 2012

Accepted November 30, 2012

Published March 11, 2013

DOI http://dx.doi.org/10.4238/2013.March.11.7

\begin{abstract}
The fragmentation of the original vegetation of the Cerrado biome, caused by the expansion of agricultural areas, mainly in central-west Brazil, calls for an assessment of the native population of this vegetation, especially of the species of interest for domestication and sustainable use. The purpose of this study was to characterize the genetic diversity of 140 gabiroba mother plants (Campomanesia spp) and their progenies from 17 locations in Goiás. The morphological characteristics of the mother plants were evaluated, and the leaflets were collected for molecular analysis using 12 random amplified polymorphic DNA primers. The seed progenies of these matrices were transplanted to the field and morphologically evaluated. Distance matrices of the morphological data of the mother plants and progenies as well as the molecular data of the mother plants were constructed, and groups were formed using the Tocher method and the unweighted pair-group method based on arithmetic averages. The polymorphism level in the matrix was $90.44 \%$. The greatest molecular distance $(0.66)$
\end{abstract}


was observed between mother plants from Santa Rita do Araguaia and Alexânia. By the Tocher method, 10, 13, and 17 groups were formed. The morphological evaluation of the mother plants and progenies as well as the molecular analysis of the mother plants showed genetic diversity. Significant genetic variability was detected in the progenies of the gabiroba base collection planted in Campus Jataí, Goiás.

Key words: Multivariate techniques; Genetic variability; Germplasm; Cerrado; Conservation

\section{INTRODUCTION}

The Cerrado biome is considered a hotspot of genetic diversity [CI (Conservation International), 2009], covering approximately $22 \%$ of the Brazilian territory, of which $90 \%$ is in the states of São Paulo, Minas Gerais, Mato Grosso, Goiás, and Bahia (Fonseca and Muniz, 1992). This is the second largest biome in Brazil, but it has been rapidly fragmented in recent years (Silva et al., 2009) by rapid agricultural expansion (Calaça and Dias, 2010). Currently, the Cerrado, a tropical savanna in Brazil, is one of the most threatened biomes on the planet (Aquino et al., 2007). In view of the fragmentation of the original Cerrado vegetation, and considering that many native plant species produce edible fruits (Silva et al., 1994) or fruits with promising organoleptic characteristics and market potential (Melchior et al., 2006), further studies are required to generate information for the conservation, domestication, and improvement of species diversity.

Among the fruit species in the Cerrado biome, the gabiroba (Campomanesia spp, Myrtaceae), also known in Brazil as guabiroba, gabiroba-do-mato, gabiroba-do-campo, guavira, or cambucizeiro, is particularly interesting. Gabiroba fruits can be consumed raw or processed in a range of products, from sweets and ice cream (Freitas et al., 2008) to liquors (Vallilo et al., 2006). The species is also used in the cosmetic industry and for herbal remedy production because gabiroba leaves contain essential oils (Vallilo et al., 2005). Clement et al. (2001) classified gabiroba as a species in the initial domestication phase because studies on the genetic improvement of gabiroba have been published.

Currently, the genetic variability of gabiroba is under study, using a combination of classical techniques (morphometry) together with molecular tools (Hršak et al., 2011; Nandini et al., 2011). Random amplified polymorphic DNA (RAPD) markers are particularly useful when little is known about the genetic structure of a species. In this context, morphological data combined with molecular markers has been used to characterize the genetic diversity and variability (Gomes Filho et al., 2010). However, the quantification of phenotypic diversity among accessions is feasibly only when the phenotypic divergence reflects the genetic divergence (Dias and Kageyama, 1991) because environmental effects and gene action can complicate this assessment (Andrade et al., 2011). The results of the combination of both tools (morphometry and RAPD makers) have proven to be satisfactory, as reported by Rodrigues et al. (2005), Hršak et al. (2011), Nandini et al. (2011), and others. The purpose of this study was to characterize the genetic diversity of gabiroba matrices from several locations in the State of Goiás on the basis of morphological data and RAPD markers, and to morphologically characterize the progenies of these matrices. 


\section{MATERIAL AND METHODS}

The study material consisted of 140 gabiroba matrices from 17 locations (origins) in Goiás: Abadiânia, Alexânia, Anápolis, Caçu, Caiapônia, Caldas Novas, Catalão, Goiânira, Jataí, Mineiros, Ouvidor, Pirenópolis, Quirinópolis, Rio Verde, Santa Rita do Araguaia, Serranópolis, and Três Ranchos. At each location, at least eight matrices were randomly selected. From Quirinópolis, only five mother plants could be selected for this study. Morphological data and leaves of each mother plant were collected for morphological analysis and DNA extraction/ RAPD analysis, respectively, and fruits for seeds were collected to establish progenies.

\section{Morphological characterization}

The mother plants were morphologically characterized on the basis of the following traits: fruit length, fruit diameter, peduncle length, number of seeds, and Brix degree. Each mother plant was assessed seven times, and the analyses were based on the averaged results. Seeds from the fruits of the matrices were germinated in plastic pots filled with a commercial substrate (Plantimex ${ }^{\circledR}$ ) at $25^{\circ} \pm 5^{\circ} \mathrm{C}$ and irrigated twice daily, generating 140 progenies. These progenies were transplanted to the field, 120 days after sowing. Four progenies per plot were planted in a randomized block design with four replications, with a row spacing of $2 \mathrm{~m}$ and a plant spacing of $1 \mathrm{~m}$. The initial progeny development was evaluated 230 days after transplanting. The following morphological characteristics were evaluated: plant height, number of leaves, stem diameter at the soil base, diameter of the fully developed leaf, and the length of the fully developed leaf.

\section{Statistical analysis of morphological data}

The dissimilarity matrices of the mean morphological data for the mother and progeny plants were constructed on the basis of the standardized mean Euclidean distance. The groups were clustered by the method proposed by Tocher, as mentioned by Rao (1952) and by the unweighted pair-group method based on arithmetic averages (UPGMA) algorithm, according to Sneath and Sokal (1973). Analyses were performed using GENES (Cruz, 2008) and Statistica (Statsoft Inc., 1999).

\section{Molecular analysis with RAPD markers}

Genomic DNA of the mother plants was extracted as described by Doyle and Doyle (1990) from $50 \mathrm{mg}$ leaf tissue. DNA was amplified according to Barros et al. (2005). To obtain the RAPD markers, 12 Operon ${ }^{\circledR}$ primers were used: OPA (01, 04, 08, 09, 18, and 20), OPM (03), OPS (07), OPV (05 and 12), OPAB (09), and OPAF (05). These primers were selected for providing amplification products with defined polymorphisms. Amplifications were performed in a thermocycler for 40 cycles, each with the following sequence: $15 \mathrm{~s}$ at $94^{\circ} \mathrm{C}, 30 \mathrm{~s}$ at $35^{\circ} \mathrm{C}$, and $90 \mathrm{~s}$ at $72^{\circ} \mathrm{C}$. The final extension was performed for $6 \mathrm{~min}$ at $72^{\circ} \mathrm{C}$. The amplified fragments were separated by electrophoresis on a $1.5 \%$ agarose gel stained with $0.2 \mathrm{mg} /$ $\mathrm{mL}$ ethidium bromide and immersed in TBE buffer ( $90 \mathrm{mM}$ Tris-Borate, $1 \mathrm{mM}$ EDTA), for approximately $390 \mathrm{~min}$ at $90 \mathrm{~V}$. At the end of the electrophoresis, the gels were photographed with an ultraviolet transilluminator. 


\section{Statistical analysis of molecular data}

The RAPD markers were converted into a binary data matrix, underlying the estimation of the genetic distances between the 140 mother plants in the 17 locations, based on the complement of the similarity coefficient of Nei and Li (1979). The genetic distances between the mother plants were used for cluster analysis, as described by Tocher and quoted by Rao (1952), and the genetic distances of the plants from the 17 locations were used for clustering by the UPGMA algorithm according to Sneath and Sokal (1973). Analyses were performed using GENES (Cruz, 2008) and Statistica (Statsoft Inc., 1999).

Bootstrapping of the loci was used to estimate the coefficient of variation of the similarity index of Nei and Li, with 1000 permutations (Tivang et al., 1994) using Dboot (Coelho, 2000). The exponential function $\mathrm{y}=\mathrm{ax}^{\mathrm{b}}$ best fit the data, and the minimum number of loci was estimated by the following expression:

$$
x_{c}=\left[\mathrm{aa}^{2} b^{2} \frac{(2 b-1)}{(b-2)}\right]^{\frac{1}{(2-2 b)}}
$$

where $x_{c}$ is the point of the maximum curvature of the function, corresponding to the minimum number of loci to be sampled. The measure of heterogeneity among the bands was also estimated by parameter $b$ of the equation $\mathrm{y}=\mathrm{ax}^{\mathrm{b}}$, with a maximum of 0.5 , according to Pequeno et al. (2003).

To determine the groups, a distance shift or level change was used in the dendrogram, according to Dias (1998). The cophenetic correlation coefficient was also calculated, which according to Odong et al. (2011) is a measure of the association between the data pairs generated by the distances between the mother plants and the distances in the dendrogram.

\section{RESULTS}

The molecular analysis results showed that the 12 selected primers for the 140 gabiroba mother plants produced 178 bands, with an average of 14.83 bands per primer. The OPA $(09,18$, and 20), OPV (12), and OPAB (09) primers produced the most (14-18) polymorphic bands. A polymorphism level of $90.44 \%$ was observed (Table 1 ). The polymorphism rate of the genotypes was higher than $60 \%$ in the intra-location analysis and greater than $80 \%$ in the inter-location analysis.

Analyzing the minimum number of bands (Bootstrap) to ensure a reliable genome sampling (Table 1) of the 140 mother plants, only 120 polymorphic bands were necessary. In the analysis of the 17 locations studied, 20 of the 80 polymorphic bands were necessary. However, within the locations, 30-70 polymorphic bands were required to quantify the diversity. The greatest number of polymorphic bands ( 70 bands) was necessary to quantify the diversity between genotypes in Caiapônia, Jataí, and Pirenópolis. The heterogeneity between the bands varied from 0.43 to 0.50 within the origin and was 0.49 among the origin. When evaluating the 140 matrices, the heterogeneity value was 0.37 .

The dissimilarity between the 140 mother plants ranged from 0.072 to 0.660 , av- 
eraging 0.420 . The highest dissimilarity (0.660) was observed between mother plants 11 and 91 from Alexânia and Santa Rita do Araguaia, respectively, which are located $627 \mathrm{~km}$ apart, and the lowest dissimilarity (0.072) was observed between mother plants 57 and 58 from Caldas Novas and Goiânira, respectively, separated by $196 \mathrm{~km}$. The dissimilarity between the locations ranged from 0.094 to 0.32 , with an average of 0.199 , with the lowest dissimilarity (0.094) found between Abadiânia and Anápolis, which are $37.4 \mathrm{~km}$ apart, and the greatest dissimilarity $(0.32)$ found between Mineiros and Serranópolis, which are separated by $144 \mathrm{~km}$.

Table 1. Percentage of polymorphism (\% Pol), minimum number of bands required for a representative sampling of the genome (MN), and the heterogeneity degree (b) detected in plants from each location, among locations (AL) and among the 140 gabiroba genotypes (AGG).

\begin{tabular}{|c|c|c|c|c|}
\hline Location & No. of bands & $\% \mathrm{Pol}$ & MN & $\mathrm{b}$ \\
\hline $\mathrm{Ab}$ & 138 & 79.71 & 50 & 0.470 \\
\hline $\mathrm{Al}$ & 118 & 72.03 & 60 & 0.430 \\
\hline $\mathrm{An}$ & 140 & 68.34 & 30 & 0.480 \\
\hline Cç & 150 & 78.86 & 40 & 0.440 \\
\hline $\mathrm{Ca}$ & 123 & 80.00 & 70 & 0.470 \\
\hline $\mathrm{Cn}$ & 131 & 67.93 & 30 & 0.475 \\
\hline $\mathrm{Ct}$ & 123 & 80.48 & 30 & 0.477 \\
\hline G & 124 & 60.97 & 40 & 0.494 \\
\hline J & 150 & 84.66 & 70 & 0.443 \\
\hline M & 152 & 80.79 & 60 & 0.478 \\
\hline $\mathrm{O}$ & 111 & 69.64 & 30 & 0.470 \\
\hline P & 146 & 79.45 & 70 & 0.460 \\
\hline Q & 104 & 61.53 & 35 & 0.500 \\
\hline $\mathrm{RV}$ & 148 & 81.75 & 60 & 0.475 \\
\hline SR & 123 & 80.27 & 60 & 0.473 \\
\hline $\mathrm{Se}$ & 146 & 75.00 & 50 & 0.467 \\
\hline $\mathrm{T}$ & 109 & 65.24 & 30 & 0.491 \\
\hline $\mathrm{AL}$ & 176 & 80.00 & 20 & 0.495 \\
\hline AGG & 178 & 90.44 & 120 & 0.374 \\
\hline
\end{tabular}

In the cluster analysis of the morphological data of the mother plants and progenies, and of the molecular data of the mother plants (Table 2) by the Tocher method, the values obtained by the distance limit between the groups (highest minimum) were 1.21, 1.01, and 0.32 , respectively. Thus, 10,13 , and 17 grouped with. The distances for morphological data of the mother and progeny plants and of the molecular data of the mother plants, at the intragroup level, were $0.54-1.07,0.59-1.01$, and $0.24-0.32$, respectively, for intergroup evaluation distances of 1.29-2.71, 1.02-3.65, and 0.33-0.61, respectively. The highest dissimilarities were detected between groups 3 and 5, 8 and 13, and 9 and 15, respectively.

In the UPGMA clustering of locations based on morphological data of the mother plants and progenies, and of the molecular data of the mother plants, six distinct groups were formed in all dendrograms (Figure 1). The cophenetic correlation coefficients for the morphological data for the mother plants were 0.94 and 0.79 for the progenies and 0.82 for the molecular data of the mother plants. The dissimilarity observed in the morphological analysis of the mother plants (Figure 1A) varied from 0.39 to 3.46. Jataí and Serranópolis (58.9 km apart) were the most divergent locations, and Quirinópolis and 
Pirenópolis (415 km apart) were the least divergent locations. The formation of a group of 12 locations was observed, whereas the other groups consisted of isolated locations (Serranópolis, Jataí, Caiapônia, Santa Rita do Araguaia, and Mineiros). In the progeny group (Figure 1B), as determined from the morphological data of the initial development, the dissimilarity varied from 0.17 to 2.98 , and the most divergent locations were Jataí and Catalão (509 km apart), whereas the least divergent locations were Quirinópolis and Serranópolis (235 km apart). For the molecular data (Figure 1C), the dissimilarities between the locations ranged from 0.09 to 0.30 , and the most divergent locations were Goiânira and Quirinópolis, situated $306 \mathrm{~km}$ apart, whereas the least divergent locations were Abadiânia and Anápolis, $37.4 \mathrm{~km}$ apart.

Table 2. Grouping by the Tocher method of gabiroba plants, based on the morphological distance matrix of 140 mother plants, their progenies, and of molecular data of the mother plants based on RAPD markers.

\begin{tabular}{|c|c|c|c|}
\hline Groups & Morphological data of the mother plants & Morphological data of the progenies & Molecular data of the mother plants \\
\hline 1 & 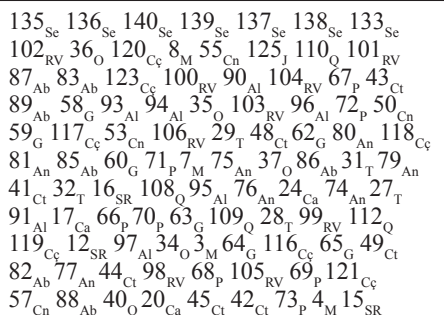 & 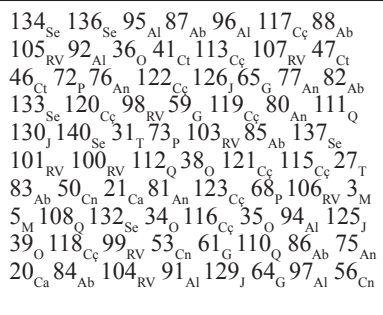 & $\begin{array}{l}57_{\mathrm{Cn}} 58_{\mathrm{G}_{6}} 60_{\mathrm{G}} 59_{\mathrm{G}} 61_{\mathrm{G}} 62_{\mathrm{G}} 56_{\mathrm{Cn}_{\mathrm{n}}} 65_{\mathrm{G}} \\
66_{\mathrm{P}} 64_{\mathrm{G}} 63_{\mathrm{G}} 55_{\mathrm{Cn}} 54_{\mathrm{Cn}} 51_{\mathrm{Cn}} 52_{\mathrm{Cn}} 50_{\mathrm{Cn}} \\
53_{\mathrm{Cn}} 49_{\mathrm{Ct}} 47_{\mathrm{Ct}} 48_{\mathrm{Ct}}\end{array}$ \\
\hline 2 & $\begin{array}{l}127_{\mathrm{J}} 129_{1}, 128_{\mathrm{J}} 131_{\mathrm{J}} 130_{\mathrm{J}} 39_{\mathrm{O}} 92_{\mathrm{Al}} 22_{\mathrm{Ca}} \\
23_{\mathrm{Ca}} 30_{\mathrm{T}} 107_{\mathrm{VV}} 122_{\mathrm{Cr}} 13_{\mathrm{SR}} 52_{\mathrm{Cn}} 21_{\mathrm{Ca}} 47_{\mathrm{Cl}} \\
10_{\mathrm{SR}} 78_{\mathrm{An}} 26_{\mathrm{T}} 11_{\mathrm{SR}} 111_{\mathrm{O}}\end{array}$ & $\begin{array}{l}33_{\mathrm{O}} 135_{\mathrm{Se}} 93_{\mathrm{Al}} 131_{\mathrm{J}} 71_{\mathrm{p}} 138_{\mathrm{Se}} 78_{\mathrm{An}} 66_{\mathrm{p}} \\
109_{\mathrm{Q}} 74_{\mathrm{An}} 55_{\mathrm{Cn}} 127_{\mathrm{J}} 32_{\mathrm{T}} 79_{\mathrm{An}} 128_{\mathrm{J}} 124_{\mathrm{J}} \\
139_{\mathrm{Se}} 114_{\mathrm{Ce}}\end{array}$ & $\begin{array}{l}129_{\mathrm{J}} 130_{\mathrm{J}} 131_{\mathrm{J}} 128_{\mathrm{J}} 127_{\mathrm{J}} 1_{\mathrm{M}} 4_{\mathrm{M}} 5_{\mathrm{M}} \\
6_{\mathrm{M}} 2_{\mathrm{M}}\end{array}$ \\
\hline 3 & $113_{\mathrm{Cq}} 115_{\mathrm{C \varphi}} 114_{\mathrm{Cq}} 1_{\mathrm{M}} 6_{\mathrm{M}} 25_{\mathrm{T}} 14_{\mathrm{SR}} 2_{\mathrm{M}} 46_{\mathrm{Ct}} 56_{\mathrm{Cn}}$ & $\begin{array}{l}28_{\mathrm{T}} 37_{\mathrm{O}} 23_{\mathrm{CG}} 43_{\mathrm{C}} 102_{\mathrm{RV}} 67_{\mathrm{p}} 244_{\mathrm{Ca}} 90_{\mathrm{Al}} \\
45_{\mathrm{C}} 44_{\mathrm{Ct}} 69_{\mathrm{p}} 30 \mathrm{~T}_{\mathrm{T}} 25_{\mathrm{T}} 49_{\mathrm{c}} 52_{\mathrm{Cn}} 70_{\mathrm{p}} 17_{\mathrm{Ca}} \\
6_{\mathrm{M}} 54_{\mathrm{Cn}} 1_{\mathrm{M}} 60_{\mathrm{G}} 57_{\mathrm{Cn}} 42_{\mathrm{Cl}} 29_{\mathrm{T}} 7_{\mathrm{M}} 58_{\mathrm{G}}\end{array}$ & 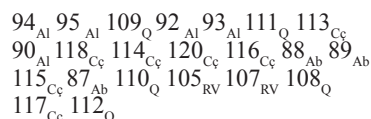 \\
\hline 4 & $61_{\mathrm{G}} 124_{\mathrm{J}} 33_{\mathrm{O}} 9_{\mathrm{SR}} 54_{\mathrm{Cn}}$ & $18_{\mathrm{Ca}} 51_{\mathrm{Cn}} 26_{\mathrm{T}} 16_{\mathrm{SR}} 9_{\mathrm{SR}}$ & 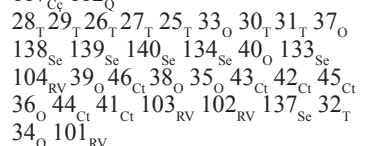 \\
\hline 5 & $132_{\mathrm{Se}} 134_{\mathrm{Se}}$ & $14_{\mathrm{SR}} 22_{\mathrm{Ca}} 2_{\mathrm{M}} 12_{\mathrm{SR}} 8_{\mathrm{M}}$ & $\begin{array}{l}77_{\mathrm{AA}} 78_{\mathrm{An}} 74_{\mathrm{P}} 73_{\mathrm{P}} 72_{\mathrm{p}} 76_{\mathrm{An}} 69_{\mathrm{p}} 68_{\mathrm{p}} \\
75_{\mathrm{AA}} 67_{\mathrm{p}} 83_{\mathrm{Ab}} 82_{\mathrm{Ab}} 81_{\mathrm{An}} 80_{\mathrm{An}} 79_{\mathrm{An}} 84_{\mathrm{Ab}} \\
85_{\mathrm{Ab}} 86_{\mathrm{Ab}} 70_{\mathrm{P}}\end{array}$ \\
\hline $\begin{array}{l}6 \\
7\end{array}$ & $\begin{array}{l}5_{M} 126_{J} 51_{C n} \\
38_{O}\end{array}$ & $\begin{array}{l}15_{\mathrm{SR}} 40_{\mathrm{O}} \\
62_{\mathrm{G}} 89_{\mathrm{Ab}}\end{array}$ & $12_{\mathrm{SR}} 13_{\mathrm{SR}} 10_{\mathrm{SR}} 15_{\mathrm{SR}} 20_{\mathrm{Ca}} 19_{\mathrm{Ca}} 21_{\mathrm{Ca}} 22_{\mathrm{Ca}}$ \\
\hline 8 & & $46^{\mathrm{B}} \mathrm{Ab}$ & $\begin{array}{l}24_{\mathrm{Ca}} 99_{\mathrm{RV}} 97_{\mathrm{Al}} 98_{\mathrm{RV}} 17_{\mathrm{Ca}} 14_{\mathrm{SR}} 100_{\mathrm{RV}} \\
16_{\mathrm{SR}} 18_{\mathrm{Ca}} 23_{\mathrm{Ca}} 9_{\mathrm{SR}}\end{array}$ \\
\hline 9 & $84_{\mathrm{Ab}}$ & $11_{\mathrm{SR}}$ & $91_{\mathrm{Al}} 96_{\mathrm{Al}} 119_{\mathrm{C} \varphi}$ \\
\hline 10 & $18_{\mathrm{Ca}}$ & $199_{\mathrm{Ca}}$ & $135_{\mathrm{Se}} 136_{\mathrm{Se}}$ \\
\hline 11 & & $48_{\mathrm{ct}}$ & $124_{\mathrm{J}} 125_{\mathrm{J}} 123_{\mathrm{Cq}_{\mathrm{q}}} 126_{\mathrm{J}}$ \\
\hline 12 & & $13_{\mathrm{SR}}$ & $121_{\mathrm{C \varphi}_{\varphi}} 122_{\mathrm{C \varphi}}$ \\
\hline 13 & & $10_{\mathrm{SR}}$ & $132_{\mathrm{Se}}$ \\
\hline 14 & & & \\
\hline $\begin{array}{l}15 \\
16\end{array}$ & & & $11_{\mathrm{SR}}$ \\
\hline $\begin{array}{l}16 \\
17\end{array}$ & & & $\begin{array}{l}106_{\mathrm{RV}} \\
71_{\mathrm{p}}\end{array}$ \\
\hline Highest & 1.21 & 1.01 & 0.32 \\
\hline
\end{tabular}

minimum

$\mathrm{Ab}=$ Abadiânia; $\mathrm{Al}=$ Alexânia; $\mathrm{An}=$ Anápolis; $\mathrm{Cc}=$ Caçu; $\mathrm{Ca}=$ Caiapônia; $\mathrm{Cn}=$ Caldas Novas; $\mathrm{Ct}=\mathrm{Catalão} ; \mathrm{G}$ $=$ Goiânira; $\mathrm{J}=$ Jataí; $\mathrm{M}=$ Mineiros; $\mathrm{O}=$ Ouvidor; $\mathrm{P}=$ Pirenópolis; $\mathrm{Q}=$ Quirinópolis; $\mathrm{RV}=$ Rio Verde; $\mathrm{SR}=$ Santa Rita do Araguaia; $\mathrm{Se}=$ Serranópolis; $\mathrm{T}=$ Três Ranchos. 
A

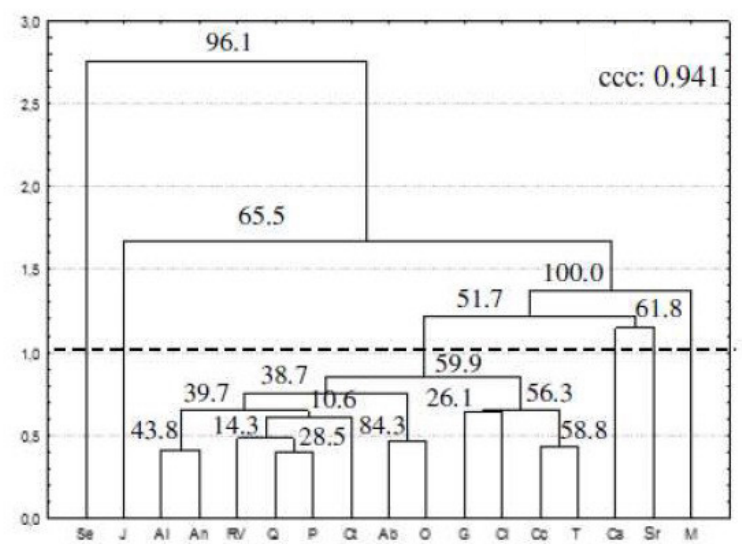

$\mathbf{B}$

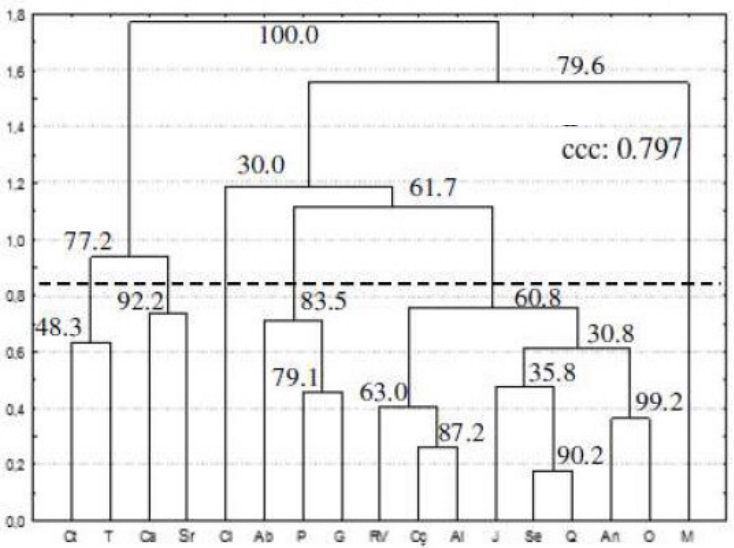

$\mathrm{C}$

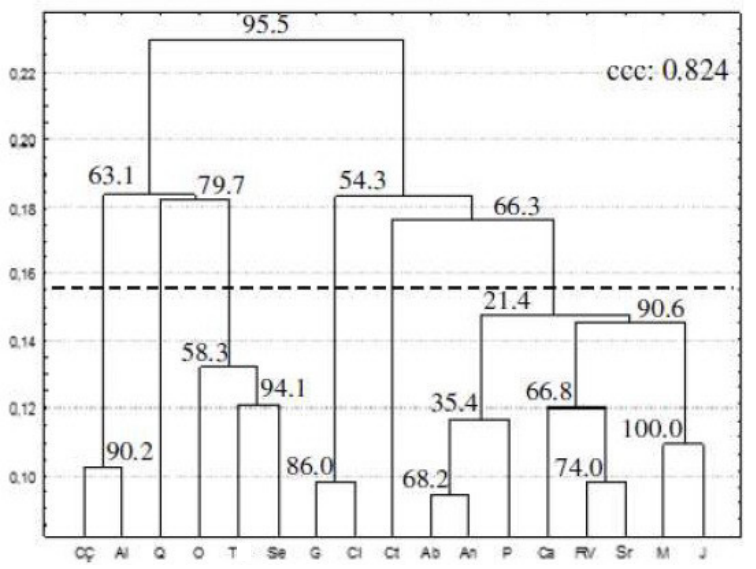

Figure 1. UPGMA dendogram of similarity distances, based on morphological data, between the mother plants (A) among the progenies $(\mathbf{B})$, and of similarity distances based on molecular data between the mother plants $(\mathbf{C})$. $\mathrm{ccc}=$ cophenetic coefficient of correlation. $\mathrm{Ab}=$ Abadiânia; $\mathrm{Al}=$ Alexânia; $\mathrm{Na}=$ Anápolis; $\mathrm{C} c ̧=\mathrm{Caçu} ; \mathrm{Ca}=\mathrm{Caiapônia}$; $\mathrm{Cn}=$ Caldas Novas; $\mathrm{Ct}=$ Catalão; $\mathrm{G}=$ Goiânira; $\mathrm{J}=$ Jataí; $\mathrm{M}=$ Mineiros; $\mathrm{O}=$ Ouvidor; $\mathrm{P}=$ Pirenópolis; $\mathrm{Q}=$ Quirinópolis; RV = Rio Verde; $\mathrm{SR}=$ Santa Rita do Araguaia; $\mathrm{Se}=$ Serranópolis; $\mathrm{T}=$ Três Ranchos. 


\section{DISCUSSION}

The polymorphism level found in this study was similar to that reported by Rodrigues et al. (2005), Junqueira et al. (2010), and Hršak et al. (2011), with polymorphism values of 97 , 95.06 , and $92.00 \%$, respectively. These polymorphisms are considered high, indicating that the mother plants studied constitute a representative sample of the genetic diversity of gabiroba.

The percentage of polymorphism resulting from the intra-location analysis identified genetic variability even between geographically close genotypes. The locations where polymorphism is greater may be important for preservation of the genetic resources or for specimen collection for breeding programs. The high polymorphism may be explained by the initial domestication phase of this plant as well as by cross-pollination, which tends to favor increased gene flow, suggesting an absence of selection that could favor the maintenance of gene polymorphisms in successive generations.

The results of the bootstrapping analysis allowed conclusions regarding the effort and resources required to obtain molecular data in further research on gabiroba because the establishment of a higher number of polymorphic bands would not necessarily increase the accuracy of the analysis. For this study, we observed that the number of polymorphic bands generated by the 12 primers was well above the minimum quantity of polymorphic bands (considered adequate and necessary for bootstrapping analysis) in all structures, demonstrating that the genome sampling was satisfactory and the results were significant.

The heterogeneity values among the bands for inter- and intra-location data may be considered high because these values were close to 0.5 , which is considered the maximum value for heterogeneity (Pequeno et al., 2003). In contrast, the heterogeneity observed on the evaluation of all mother plants was lower than that observed from the inter- and intra-location data, demonstrating a reduction in heterogeneity when all 140 mother plants were considered and thus indicating the occurrence of similar bands in mother plants from different locations.

Clustering by the Tocher method, based on both morphological and molecular data, showed that the mother plants and progenies did not group according to the location. The clustering also demonstrated that the most divergent groups consisted of mother plants and progenies from both geographically distant and close locations, demonstrating that the genetic variability of the plants is distributed throughout the study area. Particularly, the mother plants from Caçu, Mineiros, Rio Verde, Santa Rita do Araguaia, and Serranópolis showed greater divergence because the genotypes were distributed in more than three groups, indicating that the genetic variability at these locations is relatively greater.

The cophenetic correlation coefficients of the progeny grouping according to the UPGMA method, based on the morphological data of the mother plants and the progenies as well as the molecular data of the mother plants, were $>0.797$, demonstrating a good representation of the original distances in the dendrograms, as reported by Cruz et al. (2011). The distribution of the locations within the dendrogram groups showed coincidence of groups based on the morphological data of mother plants and progenies, although the assessed characteristics were different. In the first case, fruit-related traits were evaluated, and in the second case, traits related to the early development of the progenies were evaluated. The UPGMA clustering based on the molecular data, however, showed little correlation to the morphological data. In the largest group of similar locations, five locations were in the southwestern region of Goiás (Jataí, Mineiros, Santa Rita do Araguaia, Caiapônia, and Rio Verde), but geographically 
distant locations with similar plants were also observed, as for Alexânia and Caçu.

In conclusion, RAPD markers and morphological data allowed the quantification of genetic diversity in natural gabiroba populations. The results indicated that the number of collection locations could be reduced, resulting in time and cost savings during the collection expeditions. The genetic diversity detected for the 140 mother plants in the present study demonstrated the potential for future research on the in situ or ex situ conservation of these plants and for plant breeding. The genetic variability in the gabiroba base collection in Campus Jataí is significant.

\section{ACKNOWLEDGMENTS}

Research supported by Conselho Nacional de Desenvolvimento Científico e Tecnológico (CNPq) and Fundação de Amparo à Pesquisa do Estado de Goiás (FAPEG).

\section{REFERENCES}

Andrade RA, Wichert E, Martins ABG, Andrade MMC, et al. (2011). Diversidade genética de acessos de Nephelium lappaceum L. através de caracterização morfológica e molecular. Comum. Scient. 2: 91-99.

Aquino FG, Walter BMT and Ribeiro JF (2007). Espécies vegetais de uso múltiplo em reservas legais de Cerrado - Balsas, MA. Rev. Bras. Biociências 5: 147-149.

Barros AM, Faleiro FG, Karia CT, Shiratsuchi LS, et al. (2005). Variabilidade genética e ecológica de Stylosanthes macrocephala determinadas por RAPD e SIG. Pesq. Agropec. Bras. 40: 899-909.

Calaça M and Dias WA (2010). A modernização do campo no cerrado e as transformações socioespaciais em Goiás. Campo-Território. Rev. Geogr. Agrária 5: 312-332.

CI (Conservation International) (2009). The Biodiversity Hotspots. VA: Conservation International, Arlington.

Clement CR, Yuyama K and Chavez Flores WB (2001). Recursos Genéticos de Pupunha. In: Recursos Fitogenéticos na Amazônia Ocidental: Conservação, Pesquisa e Utilização (Souza NR and Souza AGC, eds.). Editora Embrapa Amazônia Ocidental, Manaus, 143-187.

Coelho ASG (2000). Dboot: Avaliação dos Erros Associados a Estimativas de Distâncias/Similaridades Genéticas Através do Procedimento de Bootstrap com Número Variável de Marcadores (Softwares). Laboratório de Genética Vegetal, Instituto de Ciências Biológicas, UFG, Goiânia.

Cruz CD (2008). Programa Genes - Diversidade Genética. Editora UFV, Viçosa.

Cruz CD, Ferreira FM and Pessoni LA (2011). Biometria Aplicada ao Estudo da Diversidade Genética. Editora Suprema, Visconde do Rio Branco.

Dias LAS (1998). Análises Multidimensionais. In: Eletroforese de Isoenzimas e Proteínas Afins: Fundamentos e Aplicações em Plantas e Microrganismos (Alfenas AC, ed.). Editora UFV, Viçosa, 405-475.

Dias LAS and Kageyama PY (1991). Variação genética em espécies arbóreas tropicais e conseqüências para o melhoramento florestal. Agrotrópica 3: 119-127.

Doyle JJ and Doyle JL (1990). Isolation of plant DNA from fresh tissue. Focus 12: 13-15.

Fonseca CEL and Muniz IAF (1992). Informações sobre a cultura de espécies frutíferas nativas da região dos cerrados. Informe Agropec. 16: 2-16.

Freitas JB, Cândido TLN and Silva MR (2008). Geléia de gabiroba: Avaliação da aceitabilidade e características físicas e químicas. Pesq. Agropec. Trop. 38: 87-94.

Gomes Filho A, Oliveira JG, Viana AP, Siqueira APO, et al. (2010). Marcadores moleculares RAPD e descritores morfológicos na avaliação da diversidade genética de goiabeiras (Psidium guajava L.). Acta Sci. Agron. 32: 627-633.

Hršak V, Brana S, Sedlar Z and Pejić I (2011). Morphometric and molecular (RAPD) analysis of six Serapias taxa from Croatia. Biologia 66: 55-63.

Junqueira KP, Faleiro FG, Bellon G, Junqueira NTV, et al. (2010). Variabilidade genética de acessos de pitaya com diferentes níveis de produção por meio de marcadores RAPD. Rev. Bras. Frutic. 32: 840-846.

Melchior SJ, Custodio CC, Marques TA and Machado Neto NB (2006). Colheita e armazenamento de sementes de gabiroba (Campomanesia adamantium Camb. - Myrtaceae) e implicações na germinação. Rev. Bras. Sementes 28: 141-150. 
Nandini R, Singh TR and Dhanapal GN (2011). Morphometric and molecular diversity studies in tamarind (Tamarindus indica Linn.) population. J. Plant Mol. Biol. Biotechnol. 2: 26-33.

Nei M and Li WH (1979). Mathematical model for studying genetic variation in terms of restriction endonucleases. Proc. Natl. Acad. Sci. U. S. A. 76: 5269-5273.

Odong TL, van Heerwaarden J, Jansen J, van Hintum TJ, et al. (2011). Determination of genetic structure of germplasm collections: are traditional hierarchical clustering methods appropriate for molecular marker data? Theor. Appl. Genet. 123: 195-205.

Pequeno SA, Pinheiro JB, Zucchi MI, Vencosvsky R, et al. (2003). Determinação do número de marcadores RAPD para estudos da diversidade genética em soja utilizando o método BOOTSTRAP. Biosci. J. 19: 45-48.

Rao CR (1952). Advanced Statistical Methods in Biometric Research. John Wiley and Sons Inc., New York.

Rodrigues DP, Astolfi Filho S and Clement CR (2005). Molecular marker-mediated validation of morphologically defined landraces of pejibaye (Bactris gasipaes) and their phylogenetic relationships. Genet. Resour. Crop Evol. 51: 871-882.

Silva GO, Pereira AS, Souza VQ, Castro CM, et al. (2009). Distâncias genéticas entre genótipos de batata a partir de dados morfológicos, moleculares e genealógicos. Semina: Ciênc. Agrárias 30 (Supl. 1): 983-992.

Silva JA, Silva DB, Junqueira NTV and Andrade LRM (1994). Frutas Nativas dos Cerrados. Editora Embrapa, Brasília.

Sneath PHA and Sokal RR (1973). Numerical Taxonomy. W.H. Freeman and Company, San Francisco.

Statsoft Inc. (1999). Statistica for Windows (Computer Program Manual), Tulsa.

Tivang JG, Nienhius J and Smith OS (1994). Estimation of sampling variance of molecular marker data using the bootstrap procedure. Theor. Appl. Genet. 89: 259-264.

Vallilo MI, Garbelotti ML, Oliveira E and Lamardo LCA (2005). Características físicas e químicas dos frutos do cambucizeiro (Campomanesia phaea). Rev. Bras. Frutic. 27: 241-244.

Vallilo MI, Lamardo LCA, Gaberlotti ML, Oliveira E, et al. (2006). Composição química dos frutos de Campomanesia adamantium (Cambessédes) O. Berg. Ciênc. Tecnol. Alimentos 26: 805-810. 